\title{
Taxation and Budget Reform Commission (TBRC) Statutory Recommendation: Ballot Summary Length ${ }^{1}$
}

Rodney L. Clouser²

A series of 16 fact sheets has been written on statutory and constitutional proposals adopted by the Taxation and Budget Reform Commission (TBRC). The publications in this series can be accessed at http://edis.ifas.ufl.edu. Fact sheets FE733 through FE741 address statutory changes and fact sheets FE742 through FE748 address constitutional amendments. These fact sheets should not be considered as an all-inclusive assessment of the statutory or constitutional changes recommended by the Taxation and Budget Reform Commission. Some details of proposed changes may not have been discussed due to space limitations. These fact sheets are not intended as a replacement for personal knowledge about actual or proposed changes but are a guide to inform the public on the issues.

\section{Introduction}

The Taxation and Budget Reform Commission (TBRC) has made a statutory recommendation to the Florida Legislature concerning ballot summary length. The recommendation essentially exempts or releases the TBRC and the Constitutional Revision Commission (CRC) from being limited to ballot summaries of 75 words for proposed constitutional amendments. Citizen-led initiatives for proposed constitutional amendments will still be limited to ballot summaries of 75 words.

\section{TBRC Justification and Summary of the Statutory Recommendation}

Several reasons are given for the change in ballot summary length by the TBRC and CRC. According to staff analysis, the 75-word limit may be an "unconstitutional restraint on TBRC and CRC authority." The argument is made that the authority of these two bodies is wide-ranging, far-reaching and, in essence, equal to that of the legislature.

Like the legislature, constitutional amendments proposed by the TBRC and CRC are not bound by the single subject limit although the constitution specifies that citizen initiatives are limited to a single subject. Amendments not limited to a single subject may require longer explanations. The staff analysis also suggested that constitutional amendments proposed by the TBRC and CRC may be complex and therefore require more than a 75-word explanation. It is also noted that some court decisions anticipate that ballot summaries should educate voters and this may not be accomplished with a 75-word limit.

1. This is EDIS document FE735, a publication of the Food and Resource Economics Department, Florida Cooperative Extension Service, Institute of Food and Agricultural Sciences, University of Florida, Gainesville, FL. Published July 2008. Please visit the EDIS website at http://edis.ifas.ufl.edu.

2. Rodney L. Clouser, professor and extension public policy specialist of the Food and Resource Economics Department, Florida Cooperative Extension Service, Institute of Food and Agricultural Sciences, University of Florida, Gainesville, FL.

The Institute of Food and Agricultural Sciences (IFAS) is an Equal Opportunity Institution authorized to provide research, educational information and other services only to individuals and institutions that function with non-discrimination with respect to race, creed, color, religion, age, disability, sex, sexual orientation, marital status, national origin, political opinions or affiliations. U.S. Department of Agriculture, Cooperative Extension Service, University of Florida, IFAS, Florida A. \& M. University Cooperative Extension Program, and Boards of County Commissioners Cooperating. Larry Arrington, Dean 
It is specifically noted how ballot summaries have increased significantly in length over the past 40 years. The staff analysis also provides an historical perspective on the initial 75-word limit, noting for example, that the 5-word limit was needed to provide space on voting machines to display ballot summaries for multiple amendments" and that voting technology has since changed and improved.

Finally, the staff analysis suggested that TBRCand CRC-proposed constitutional amendments are formulated through a deliberative process that includes public testimony, open meetings, and public meetings, and therefore should be treated differently from citizen-led initiatives.

\section{Impact of Proposed Statutory Change}

The only impact noted and associated with the proposed statutory change is that it may cost more to print ballots. However, no mention is made of impacts, such as if voters actually read the ballot summary when voting, then the time required to vote may be longer, or that some voters may not understand the complex nature of "long-winded" ballot summaries. It is also not pointed out that the TBRC and CRC are, in reality, advocacy groups with an express intent to have their recommendations adopted by Florida voters. This may lead to questions about the biases of these groups being expressed in the ballot summary.

\section{Summary}

The proposed change in the ballot summaries for constitutional amendments made by the TBRC and CRC seems to be unremarkable, ordinary, and harmless. Fiscal costs are expected to be small and negligible. However, it cannot be overlooked that those voters who are asked to pass judgment on the proposed amendments may not understand lengthy summaries on complex subjects.

Although the statutory recommendations have been made by the TBRC, and in some instances with specific dates to become effective, the Florida Legislature and the Governor are not bound to the effective dates or the recommendations. Before these recommendations become law, they require approval of both the Florida Senate and House, and approval by the Governor. Citizens interested in the specific recommendations will need to follow the progress of the issue through the legislative process.

Additionally, there is no time limit for action by the legislature on the TBRC recommendations and they can be introduced in future legislative sessions if not passed during the current session.

\section{References}

Florida Taxation and Budget Reform Commission. 2008. An act relating to ballot summaries. TBRC, Tallahassee, FL (April). http://www.floridatbrc.org/pdf/SR0011_final.pdf

Florida Taxation and Budget Reform Commission. 2008. SR 11 Staff Analysis and Economic Impact Statement. TBRC, Tallahassee, FL (April). http://www.floridatbrc.org/pdf/ SR0011StaffAnalysis.pdf

Florida Taxation and Budget Reform Commission. 2008. Transmittal letter. TBRC, Tallahassee, FL (April). http://www.floridatbrc.org/pdf/ 1_24_08TransmittalLtrSR11.pdf 